\title{
The variability of DNA fingerprints in three species of swan
}

\author{
Anming Meng, \\ Royston E. Carter and \\ David T. Parkin
}

Department of Genetics, School of Medicine, Queen's Medical Centre, Nottingham NG7 2UH.

The genetic variation in three species of swans was examined by DNA fingerprinting. Human minisatellite probes detected a number of highly variable fragments in the restriction digests of total nuclear DNA. Assuming bands to be independent, the average allele frequency for minisatellite loci was $0 \cdot 154,0 \cdot 154$ and $0 \cdot 109$ for Mute, Whooper and Bewick's Swans, respectively. The pattern of band-distribution showed a certain degree of species-specificity, so that the fingerprints may reflect taxonomic affinities of the species. Pedigree analysis of a single family of Mute Swans showed that most of the variable fragments were inherited in a simple Mendelian fashion, allowing the relatedness of the individuals to be determined. DNA fingerprinting potentially provides a large number of genetic markers for studying the behavioural ecology, population genetics and evolution of swans.

\section{INTRODUCTION}

Studies of genetic variation depend upon the detection of genetic markers. From morphological characters, through biochemical variants to macromolecular markers, genetic variation has been revealed by ever more sophisticated analysis. Recent developments in recombinant DNA technology have resulted in the discovery and exploitation of yet another set of genetic markers: restriction fragment length polymorphisms (RFLPs). These have been used extensively for genomic mapping (Botstein et al., 1980; Beckmann and Soller, 1983; Drayna et al., 1984), and linkage analyses in pedigrees (Phillips et al., 1980; Reeders et al., 1985; Knowlton et al., 1986; Boylan et al., 1987), and they have had profound effects on studies of evolutionary and population genetics (e.g., Lansman et al., 1981; Quinn et al., 1987).

However, most RFLPs are dimorphisms, so their usefulness is limited by a lack of variation. DNA fingerprinting, developed in humans by Jeffreys and his colleagues (Jeffreys et al., 1985a), has revealed a subset of hypervariable "minisatellites" that share a common core sequence, and produce individual-specific hybridization patterns (Jeffreys et al., 1985b). The human minisatellite probes have been shown to cross-hybridize with homologous minisatellites present in the genomes of various vertebrates (Jeffreys, 1987; Jeffreys and Morton, 1987; Wetton et al., 1987; Burke and Bruford, 1987). They show multi-allelic variability, combined with somatic and germ-line stability, and simple Mendelian inheritance (Jeffreys et al., $1985 a, b$, . . Consequently, they can be used as highly informative genetic markers for individual recognition, the determination of parentage, and general linkage analysis.

Studies of swans Cygnus have previously concentrated upon the status and dynamics of populations, territory structure, mortality and breeding biology (Birkhead and Perrins, 1986). They have used physiognomical characters, combined with marking, to allow individuals to be recognised (Scott, 1967). Swan genetics has not been extensively studied (but see Bacon, 1980; Bacon and Andersen-Harild, 1987), although knowledge and understanding of genetic variability among swans might be important for their protection and captive breeding. This study reports on an examination of minisatellite polymorphism and variation between species using DNA fingerprinting.

\section{METHODS}

Blood samples were taken from wild Mute, Whooper and Bewick's Swans (Cygnus olor, C. 


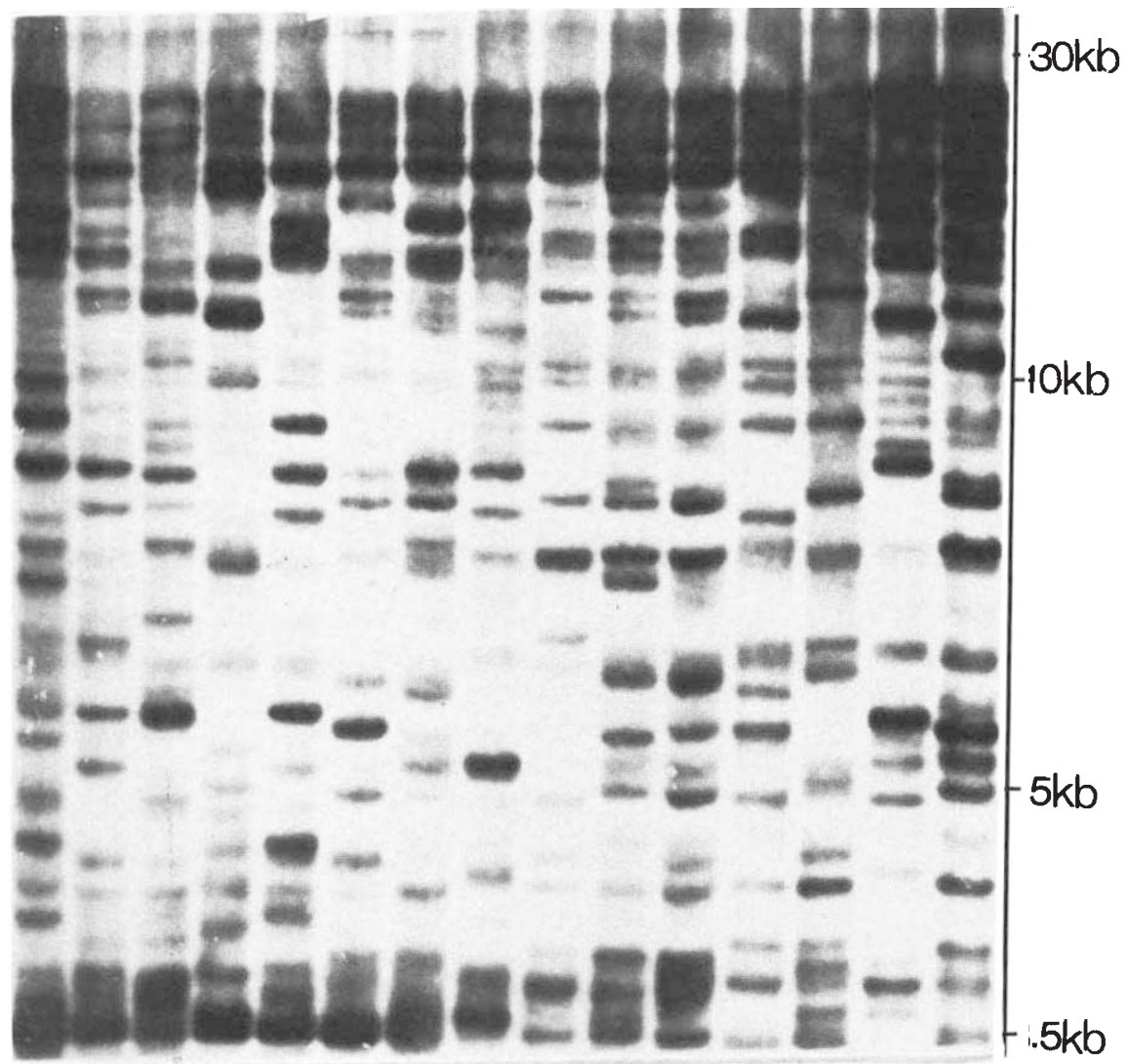

\section{$\begin{array}{lllllllllllllll}1 & 2 & 3 & 4 & 5 & 6 & 7 & 8 & 9 & 10 & 11 & 12 & 13 & 14 & 15\end{array}$}

Figure 1(a) DNA fingerprints of randomly chosen Mute Swans

cygnus and $C$. columbianus) captured at various sites in Britain. DNA was extracted and purified from frozen whole blood using methods described by Wetton et al. (1987). Samples of approximately $3 \mu \mathrm{g}$ of DNA were restricted with HaeIII, and electrophoresed in 0.8 per cent agarose gels, $22 \mathrm{~cm}$ long, until fragments less than $2.5 \mathrm{~kb}$ in length had migrated off the gel. The remaining fragments were blotted into nitrocellulose membranes, as described by Wetton et al. (1987).

The human 33.6 polycore probe was inserted into the EcoRI HindIII site of the multiple cloning site of pSPT19 to produce pSPT19.6 (Carter et al., 1989). Transcription using T7 RNA polymerase yielded a hybridization probe with very high specific activity. The blots were pre-hybridized in $1 \times \mathrm{SSC}$ and $5 \times$ Denhardt's solution at $65^{\circ} \mathrm{C}$ for 2-4 hours, and hybridized overnight at $65^{\circ} \mathrm{C}$ with the RNA probe (Carter et al., 1989). The hybridized blots were washed at $65^{\circ} \mathrm{C}$ in $0.5 \times \mathrm{SSC}$ and 0.1 per cent SDS, followed by autoradiography for 2 days at $-80^{\circ} \mathrm{C}$ using Fuji $\mathrm{RX} \mathrm{X}$-ray film and double intensifying screens.

\section{RESULTS}

\section{Variability of DNA fingerprints in Swans}

From blood samples, believed to be from unrelated birds, 15 Mute Swans, 15 Whooper Swans and five Bewick's Swans were chosen randomly. Human minisatellite probe pSPT19.6 was hybridized with blots of HaeIII-digested genomic DNA from the swans. The resulting autoradiographs are shown in figs $1(\mathrm{a}), 1(\mathrm{~b})$ and $1(\mathrm{c})$. The probe hybridized to a large number of fragments, indicating a high degree of sequence homology with human minisatellite DNA. Whether the sequence organization is similar to human minisatellite is not yet known. 


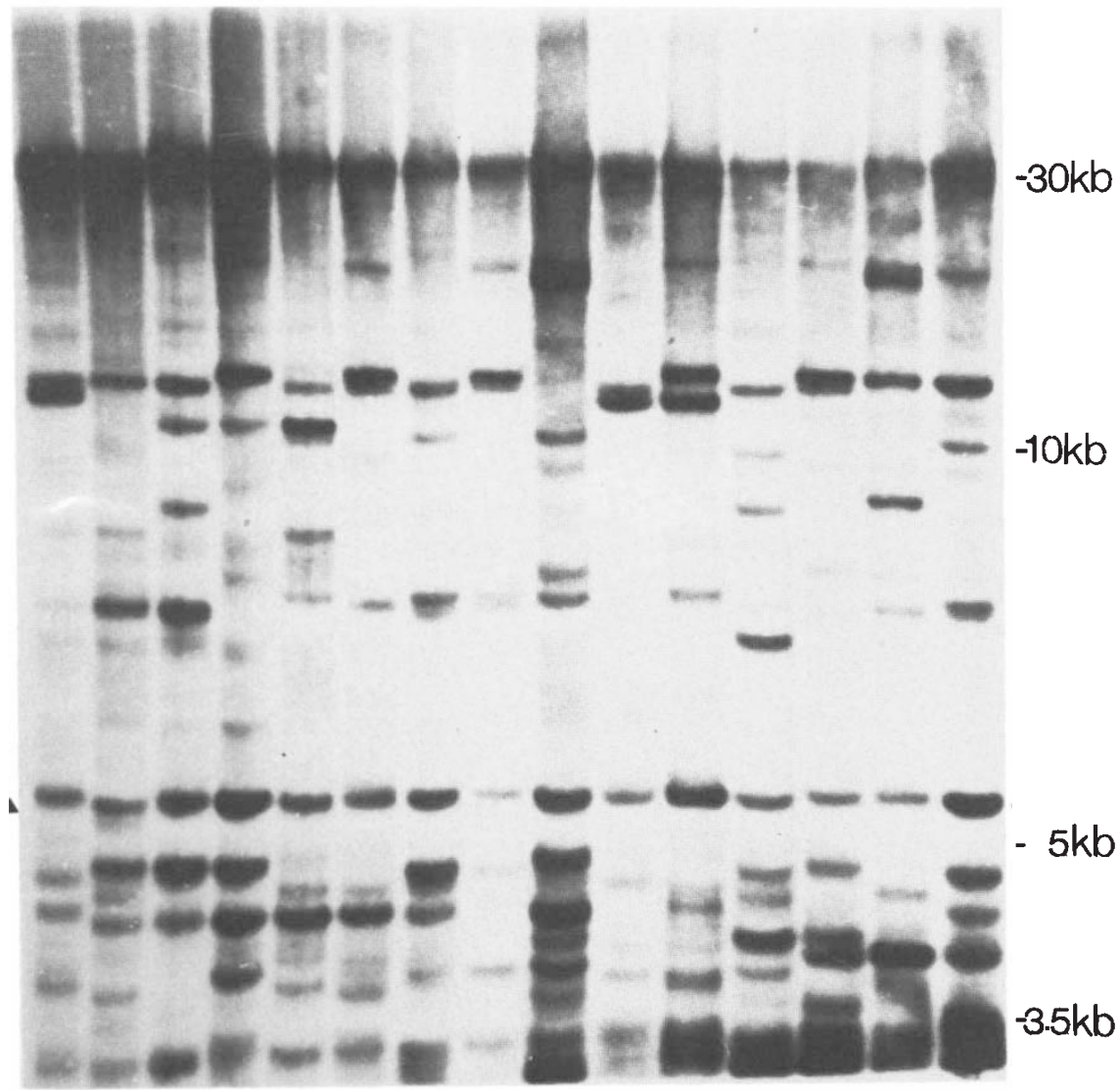

\section{$\begin{array}{lllllllllllllll}1 & 2 & 3 & 4 & 5 & 6 & 7 & 8 & 9 & 10 & 11 & 12 & 13 & 14 & 15\end{array}$}

Figure 1(b) DNA fingerprints of randomly chosen Whooper Swans A band common to all individuals is marked.

Among the Mute and Bewick's Swans (figs. 1 (a) and 1(c)), no band is present in every individual analysed. This suggests a very high degree of polymorphism (see below), as in most, if not all, other eukaryotes previously studied (Jeffreys et al., 1987; Jeffreys and Morton, 1987; Wetton et al., 1987; Burke and Bruford, 1987). The Whooper Swans (fig. 1(b)) are similarly variable: although they do all share a single band (marked in the figure). Its autoradiographic intensity varies. This monomorphic fragment might represent a minisatellite that is conserved in the evolution of Whooper Swans, but it might prove to be polymorphic or racially variable in other populations. In none of the species is there evidence of sex-linked bands, which supports the view that the minisatellite loci detected in the DNA fingerprint are dispersed through the autosomes (Jeffreys et al., 1986; Jeffreys and Morton, 1987; Wetton and Parkin, in press).
The three species do not share any bands in the size range $1-30 \mathrm{~kb}$ (fig 2 ). This suggests that there has been rapid differentiation of minisatellites among swan species, and, incidentally, that probes might be developed that could be used for specific, as opposed to individual, recognition.

The number of DNA fragments detected in the fingerprints in fig. 1 are listed in table 1 . Stringency conditions were the same for all three blots, yet the average number of bands in the size range $3 \cdot 5-30 \mathrm{~kb}$ is significantly lower in Whoopers and Bewick's than in Mutes $(p=0.05)$. This is most accounted for by a higher number of large fragments in Mute Swans, which can be seen more clearly in fig. 2. It no doubt reflects the closer taxonomic affinity of Whooper and Bewick's Swans.

The amount of variability among each species can be estimated by measuring the position of each band in fig. 1. These measurements are used to 


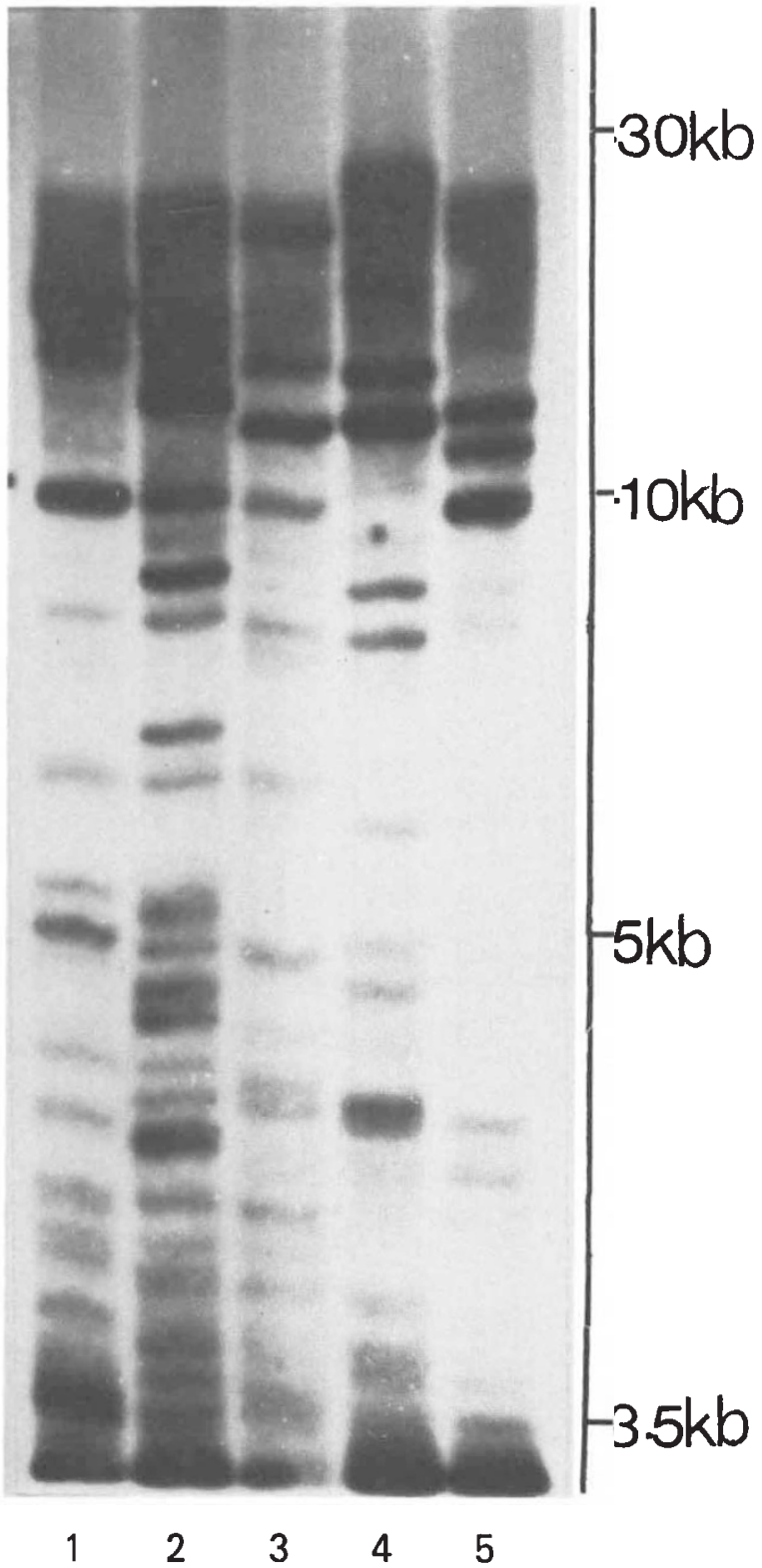

Figure 1(c) DNA fingerprints of randomly chosen Bewick's Swans

calculate the probability that a band present in one individual is matched by one of approximately similar mobility and intensity in another (Jeffreys et al., 1985b). Table 1 shows the results for all pairwise comparisons in each species, dividing the fragments into three different size categories. Comparing all three species, there is some evidence that band-sharing is higher among Mute and Whooper Swans than in Bewick's. This may reflect differences in familial relatedness of the sampled birds, or in the effective size of the population from which they came.

\section{Analysis of a single family of Mute Swans}

Fig. 3 shows the autoradiograph produced from two adult Mute Swans and the 7 cygnets that accompanied them. This allows us to examine the segregation of fragments detected in a DNA fingerprint. As with humans and other animals (Jeffreys and Morton, 1987), each band present in an offspring can be traced back to one or other parent. Lack of new length variants indicates that there is reasonable germ-line stability, although we have detected occasional 'mutant' bands in other swan pedigrees not shown here.

The birds can be compared using $\mathrm{F}=$ $2 N_{\mathrm{AB}} /\left(N_{\mathrm{A}}+N_{\mathrm{B}}\right)$ where $N_{\mathrm{AB}}$ is the number of bands apparently shared by two individuals possessing $N_{\mathrm{A}}$ and $N_{\mathrm{B}}$ bands each (Lansman et al., 1981). The value for the parents is $0 \cdot 13$, which is broadly similar to that found among unrelated house sparrows Passer domestuicus (Wetton et al., 1987). No band that is present in only one parent is transmitted to every cygnet, suggesting that all the fragments come from minisatellite loci that are heterozygous. On average, 21 pdternal fragments are transmitted to 51.4 per cent of the cygnets and 16 maternal fragments to 51.9 per cent, this being consistent with independent assortment. The number of cygnets receiving each fragment follows a binomial distribution (table 2), further supporting the view that Mute Swan minisatellites are inherited in a Mendelian fashion.

In this sibship of seven cygnets, the probability that a given pair of parental fragments cosegregates as though linked or allelic is $2 \times 0 \cdot 5^{7}=0 \cdot 016$. By pairwise comparisons of segregation of all paternal and maternal minisatellite fragments, some linkage and allelism has been found as illustrated in fig. 3 . For instance, 5 maternal fragments $(1,2,9,15$ and 16) show apparent linkage. Whether these fragments originated from a large minisatellite (approximately $60 \mathrm{~kb}$ ) with internal HaeIII recognition sites remains unknown. Their allele(s) have not been detected in the resolved size range $(3 \cdot 5-30 \mathrm{~kb})$ of the DNA fingerprints. The poor allelism in the DNA fingerprints suggests that the sizes of the two alleles at most of the minisatellite loci differ greatly. Using Jeffreys' simulation (Jeffreys et al., 1985b), the estimated total number of heterozygous loci detected in a Mute Swan DNA fingerprint is approximately 30 (data not shown). This means that the DNA fingerprints are derived from approximately 60 variable fragments. 


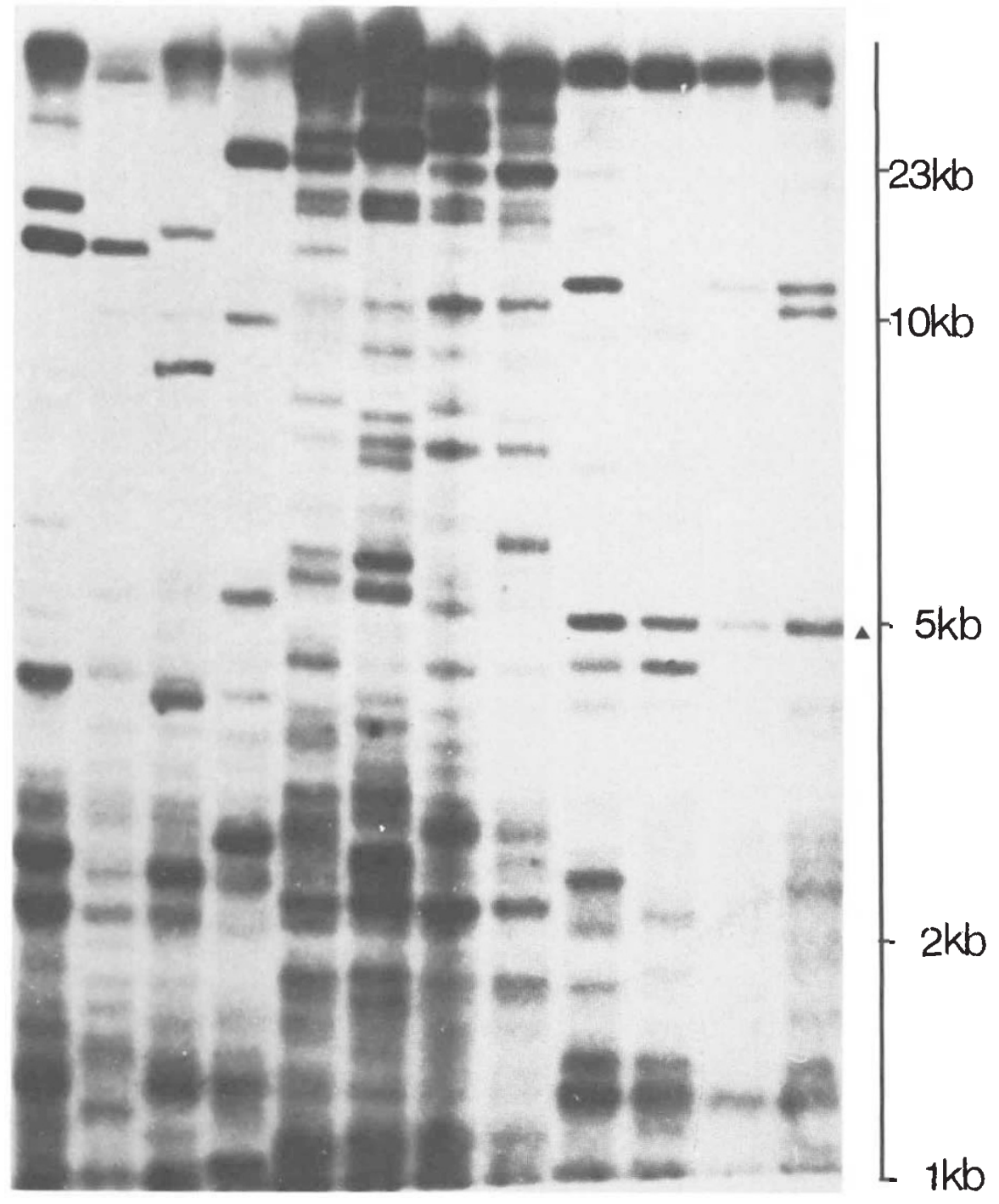

\section{$\begin{array}{lllllllllllll}\text { B1 } & \text { B2 } & \text { B3 } & \text { B4 } & \text { M1 } & \text { M2 } & \text { M3 } & \text { M4 } & \text { W1 } & \text { W2 } & \text { W3 } & \text { W4 }\end{array}$}

Figure 2 DNA fingerprints of three swan species. DNA digests from four unrelated individuals of each species were separated in the same gel at $20 \mathrm{~V}$ for 70 hrs. Hybridization was done as described above. B1-B4, Bewick's Swans; M1-M4, Mute Swans; W1-W4, Whooper Swans.

\section{Allele frequency and the uniqueness of individuals}

Jeffreys et al. (1985b) showed that the mean allele frequency at these minisatellite loci could be estimated as $q=1-(1-x)^{0.5}$, provided that any shared fragments are always derived from identical alleles. The mean allelic frequencies for the Mute and Whooper Swans are thus $0 \cdot 154$, and that for Bewick's Swan is $0 \cdot 109$. This further indicates that most minisatellite loci in swan DNA have multiple alleles $(n=6-9)$ and that very few will be homozygous.

The human minisatellite probe pSPT $19 \cdot 6$ can detect a number of swan minisatellite fragments from genomic DNA digested with HaeIII. These swan minisatellites are highly variable and constitute individual-specific DNA fingerprints, as reported in several other avian species. The Mute Swan DNA fingerprint reveals an average of 23.7 scorable bands $(n)$, with a band sharing probability ( $x$ ) of 0.284 (table 1). Assuming that the bands 

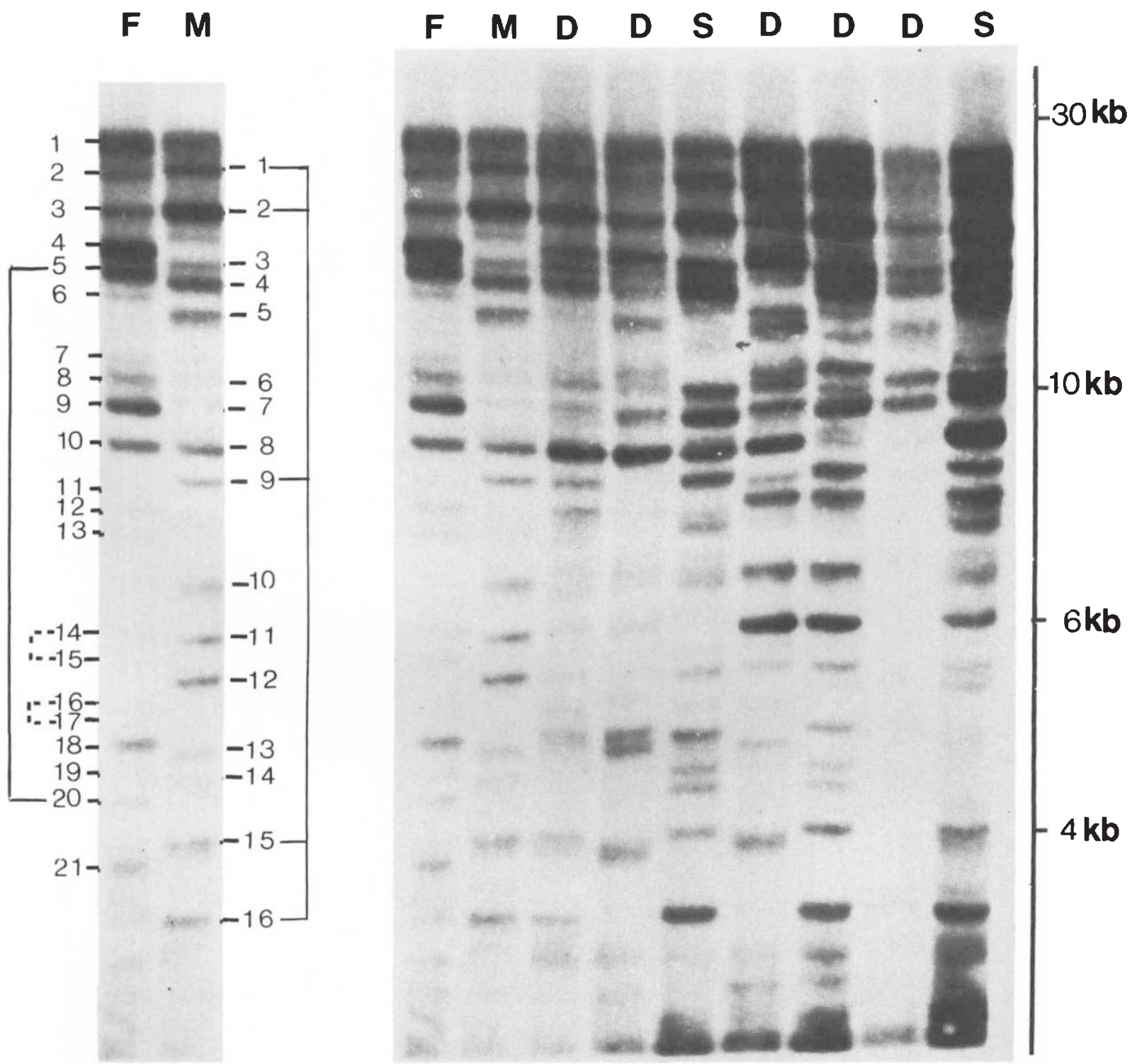

Figure 3 DNA fingerprints of a Mute Swan family. F, Father; M, Mother; D, daughter; S, son. The scored paternal (P) and maternal (M) bands, which are present in only one parent or in both parents with different intensity, were indicated. Linked parental bands that were transmitted to any offspring in the form of either ++ or -- were connected by a continuous line. Allelic parental bands that segregated into offspring of +- were connected by a dotted line. The bands were scored from original autoradiographs taken at medium and long exposure.

are independent, and that there is no linkage between minisatellite loci, the probability that two Mute Swans have identical DNA fingerprints can be estimated (Jeffreys et al., 1985b) as

$$
p=\left(1-2 x+2 x^{2}\right)^{n / x}=1 \cdot 2 \times 10^{-19}
$$

and for Whoopers and Bewicks as $7 \cdot 4 \times 10^{-15}$ and $2.9 \times 10^{-16}$ respectively. Even full-siblings from the Mute Swan family in fig. 3 have a probability of identity of $7 \cdot 3 \times 10^{-6}$. Clearly, the chance of finding two swans with a similar DNA fingerprint is extremely small.

Among the Mute Swans in Fig. 1a, there are two birds (Nos. 10 and 11) that are extremely similar. Their value of $F$ is 0.71 which is far higher than for any other pairwise comparison and well outside the range of values for parents and their offspring in fig. 3. It is similar to that for incestuous 
Table 1 Comparison of DNA fingerprints of unrelated individuals in three swan species

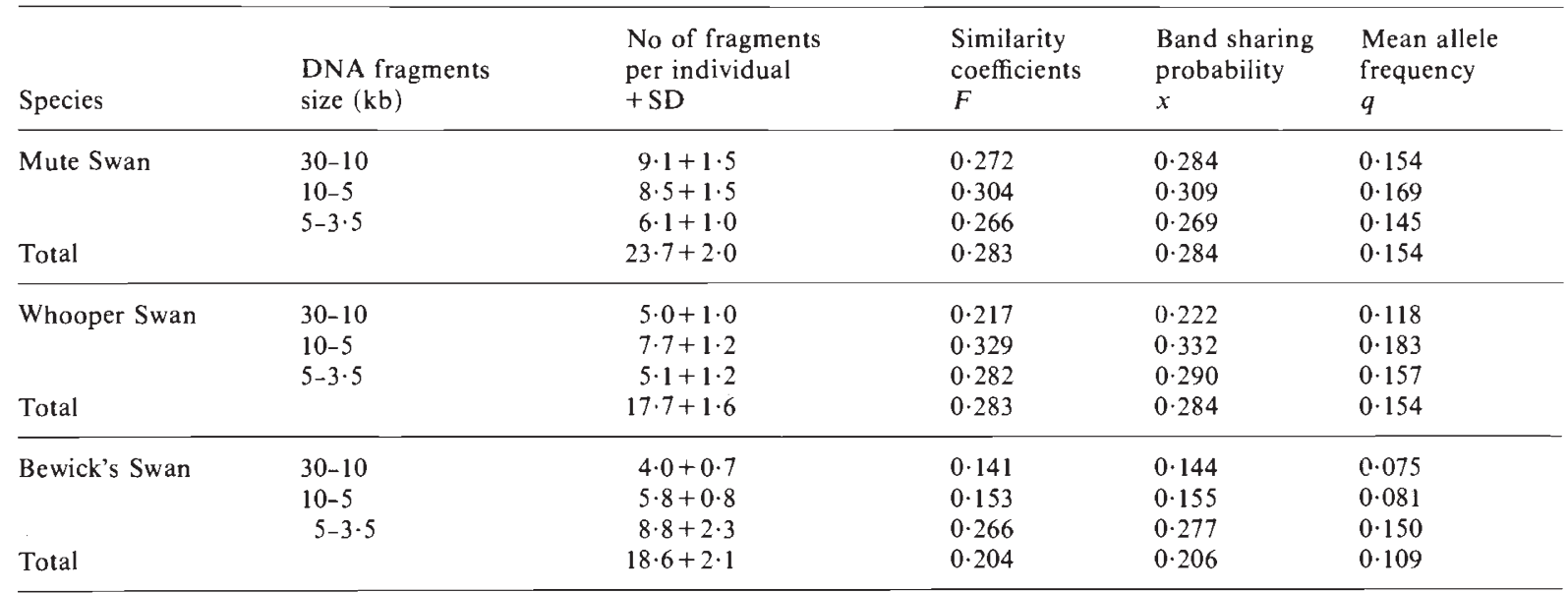

All possible non-identical pairs of DNA fingerprints in figs 1(a), 1(b) and 1(c) were compared to calculate the values of $F$ and $x$. Only those bands that have similar intensity and roughly equal mobility in two individuals were taken as shared bands; those having the same mobility but large difference in intensity are excluded from the calculation. $F$ is given by $2 N_{\mathrm{AB}} /\left(N_{\mathrm{A}}+N_{\mathrm{B}}\right)$ and $x=N_{\mathrm{AB}} / N_{\mathrm{A}}$, where $N_{\mathrm{A}}$ and $N_{\mathrm{B}}$ are the number of fragments in individuals $\mathrm{A}$ and $\mathrm{B}$, and $N_{\mathrm{AB}}$ is the number shared by both. As Nos. 10 and 11 in fig. 1(a) share many bands and are presumed to be closely related, No. 11 was discarded in estimating both $F$ and $x$. The mean allele frequency of minisatellite fragments is given by $q=1-(1-x)^{0.5}$. The probability that two individuals have identical fingerprints is given by $\mathrm{P} f=\left(1-2 x+2 x^{2}\right)^{n / x}$ where $n$ is the number of bands in a typical DNA fingerprint. Alternatively, if the individuals being compared are siblings, $\mathrm{P} f=\left[1-q(1-q)^{2}(4-q)\right]^{n / x}$.

Table 2 Segregation of parental DNA fragments in a Mute Swan family

\begin{tabular}{|c|c|c|c|c|}
\hline \multirow{2}{*}{$\begin{array}{l}\text { Transmission to } \\
\text { No. Cygnets } \\
(r)\end{array}$} & \multicolumn{2}{|c|}{ Paternal Fragments } & \multicolumn{2}{|c|}{ Maternal Fragments } \\
\hline & Observed & Expected & Observed & Expected \\
\hline 0 & 0 & $0 \cdot 17$ & 0 & $0 \cdot 12$ \\
\hline 1 & 0 & $1 \cdot 14$ & 0 & 0.82 \\
\hline 2 & 4 & $3 \cdot 44$ & 2 & $2 \cdot 46$ \\
\hline 3 & 6 & 5.74 & 4 & $4 \cdot 10$ \\
\hline 4 & 6 & $5 \cdot 74$ & 8 & $4 \cdot 10$ \\
\hline 5 & 4 & $3 \cdot 44$ & 1 & $2 \cdot 46$ \\
\hline 6 & 1 & $1 \cdot 14$ & 0 & 0.82 \\
\hline 7 & 0 & $0 \cdot 17$ & 0 & $0 \cdot 12$ \\
\hline Statistic test & \multicolumn{2}{|c|}{$\chi^{2}=1 \cdot 70, \mathrm{~ns}$} & \multicolumn{2}{|c|}{$\chi^{2}=6.54 \mathrm{~ns}$} \\
\hline $\begin{array}{l}\text { Transmission } \\
\text { frequency } \\
\text { (and s.e.) }\end{array}$ & \multicolumn{2}{|c|}{$51.4 \% \quad(7.6 \%)$} & \multicolumn{2}{|c|}{$51.9 \% \quad(5.8 \%)$} \\
\hline
\end{tabular}

Assuming that each parental fragment occurs in each cygnet fingerprint with a probability of $0 \cdot 5$, then the probability of $r$ cygnets receiving that fragment should follow a binomial distribution. The expected number of parental fragments transmitted to precisely $r$ cygnets is shown for both parents and agrees with the observed segregation patterns $(p>0.05$, in both sexes).

full siblings detected in house sparrows (Wetton et al 1987) and these swans may be similarly related.

Acknowledgements We are grateful to Dr Phillip Bacon and Dr Eileen Rees for providing the samples, and the Wildfowl Trust for permitting us to use samples collected at their Caerlaverock and Slimbridge Reserves. Dr Jon Wetton critically read the manuscript. The research was supported by the Natural Environment Research Council.

\section{REFERENCES}

BACON, P. J. 1980. Population Genetics of the Mute Swan (Cygnus olor). D.Phil. Thesis, University of Oxford. 
BACON, P. J. AND ANDERSEN-HARILD, P. 1987. Colonial breeding in Mute Swans (Cygnus olor) associated with an allozyme of lactate dehydrogenase. Biol. J. Linn. Soc., 30, 193-228.

BECKMANN, J. S. AND SOLLER, M. 1983. Restriction fragment length polymorphisms in genetic improvement: methodologies, mapping and costs. Theor. Appl. Genet., $67,35-43$.

BIRKHEAD, M. AND PERRINS, C. 1986. The Mute Swan. Croom Helm, London.

BOTSTEIN, D., WHITE, R. L., SKOLNICK, M. AND DAVIS, R. W. 1980. Construction of a genetic linkage in man using restriction fragment length polymorphism. Am. J. Hum. Genet., 32, 314-331.

BOYLAN, K., TA KABASHI, N., POPKO, B., DIAMOND, M., HOOD, L. AND PRUSINER, S. B. 1987. A highly variable region of DNA length polymorphism located adjacent to the human myelin basic protein gene. Annals of Neurology, 22, 139A.

BURKE, T. AND BRUFORD, M. W. 1987. DNA fingerprinting in birds. Nature, 327, 149-152.

CARTER, R. E., WETTON, J. H. AND PARKIN, D. T. 1989. Improved genetic fingerprinting with RNA probes. Nucleic Acids Research, 17, 5867.

DRAYNA, D., DAVIES, K., HARTLEY, D., MANDEL, J. L., CAMERINO, G., WilliamSON, R. AND White, R. 1984. Genetic mapping of the human $\mathrm{X}$ chromosome by using restriction fragment length polymorphisms. Proc. Natl Acad. Sci. USA, 81, 2836-2839.

JEFFREYS, A. J., WILSON, V. AND THEIN, S. L. $1985 a$. Hypervariable 'minisatellite' regions in human DNA. Nature, 314, 67-73.

JEFFREYS, A. J., WILSON, V. AND THEIN, S. L. 1985b. Individualspecific 'fingerprints' of human DNA. Nature, 316, 76-79.

JEFFREYS, A. J., WILSON, V., THEIN, S. L., WEATHERALL, D. J. AND PONDER, B. A. J. 1986. DNA 'fingerprints' and segregation analysis of multiple markers in human pedigrees. Am. J. Hum. Genet., 39, 11-24.

JEFFREYS, A. J., WILSON, V., KELLY, R., TAYLOR, B. A. AND BULFIELD, S. 1987. Mouse DNA 'fingerprints': analysis of chromosome localization and germ-line stability of hypervariable loci in recombinant inbred strains. Nucl. Acids Res., 15, 2823-2836.
JEFFREYS, A. J. AND MORTON D. B. 1987. DNA fingerprints of dogs and cats. Anim. Genet., 18, 1-15.

KNOWLTON, R. G., BROWN, V. A., BRAMAN, J. C., BARKER, D., SCHUMM, J. W., MURRAY, C., TAKVORIAN, T., RITZ, J. AND DONIS-KELLER, H. 1986. Use of highly polymorphic DNA probes for genotypic analysis following bone marrow transplantation. Blood, 68, 378-385.

LANSMAN, R. A., SHADE, R. O., SHAPIRA, J. F. AND AVISE, J. C. 1981 The use of restriction endonucleases to measure mitochondrial DNA sequence relatedness in natural populations. J. Mol. Evol., 17, 214-226.

PHILlipS, J. A., PENNY, S. R., KARAZIAN, H. H., BOEHM, C. D., SCOTT, A. F. AND SMITH, K. R. 1980. Prenatal diagnosis of sickle cell anaemia by restriction endonuclease analysis: Hind III polymorphisms in gamma-globin genes extend test applicability. Proc. Natl Acad. Sci. USA, 77, 2853-2857.

QUINN, T. W., QUINN, J. S., COOKE, F. AND WHITE, B. N. 1987. DNA marker analysis detects multiple maternity and paternity in single broods of the lesser snow goose. Nature, 326 , 393-394.

REEDERS, S. T., BREUNING, M. H., DAVIES, K. E., NICHOLLS, R. D., JARMAN, A. P., HIGGS, D. R., PEARSON, P. L. AND WEATHERALL, D. J. 1985. A highly polymorphic DNA marker linked to adult polycystic kidney disease on chromosome 16. Nature, 317, 542-544.

ScoTT, P. 1967. The Bewick's swans at Slimbridge. Wildfowl Trust Ann. Rep., 18, 24-27.

WETTON, J. H., CARTER, R. E., PARKIN, D. T. AND WALTERS, D. 1987. Demographic study of a wild house sparrow population by DNA fingerprinting. Nature, 327, 147-149.

WETTON, J. H. AND PARKIN, D. T. (in press) DNA fingerprinting of house sparrows. In Loxdale H. D. and Hollander, J. Den (eds) Electrophoretic Studies on Agricultural Pests Systematics Association Special Volume, Oxford University Press. 